\title{
The Content of Corporate Social Responsibility Information: The Case of Greek Telecommunication Sector
}

\author{
Grigoris Giannarakis (Corresponding author) \\ Phd Canditate - University of the Aegean, Department of Shipping Trade and Transport \\ Korai 2A, 82100, Chios, Greece \\ Tel: 30-227-103-5200Ｅ-mail: ggianaris@gmail.gr
}

Nikolaos Sariannidis

Assistant Professor - Technological Education Institute of West Macedonia

Department of Financial Applications, Kila, 50100 Kozani, Greece

E-mail: sarn@hol.gr

Alexandros E. Garefalakis

Accounting Department, Technological Education Institute of Crete

71004 Iraklio, Greece

Tel: 30-697-301-3769, 30-281-037-9646Ｅ-mail: garefalakis@teicrete.gr

Received: March 7, $2011 \quad$ Accepted: March 26, $2011 \quad$ doi:10.5539/ibr.v4n3p33

\begin{abstract}
The aim of this study is to illustrate what and how stand-alone Corporate Social Responsibility (CSR) reports and web information provide to readers. These characteristics are recorded in predetermined schemes. The study focuses on the telecommunication sector, especially on fixed and mobile telephony and internet access providers in the Greek market. In all, five companies that provide CSR reports are identified. Their characteristics are categorized by four main predetermined dimensions, namely: type of communication, context, indicators and distinctions. The content analysis technique is selected as it is widely accepted and used in the field of CSR report research. The analysis indicates that three annual reports are almost similar in all dimensions and sub-dimensions. All of the companies publish their management systems certifications and awards and both Greek and English information versions exist; however, there are contradictory results in the dimension of indicators, the sub-dimensions of report guidelines and stand-alone reports. The value of the paper is to promote the standardization of CSR report.
\end{abstract}

Keywords: Corporate Social Responsibility, Reporting, Telecommunication sector, Content Analysis

\section{Introduction}

The concept of CSR and CSR reporting has gained increased attention by numerous authors, businesses, Non Governmental Organizations (NGOs) and other bodies. Several definitions have been proposed for the concept of CSR, the majority of who refer to the satisfaction of stakeholders' expectations, needs and interests. One such definition is proposed by European Commission (2001) which states that "being socially responsible means not only fulfilling legal expectations, but also going beyond compliance and investing "more" into human capital, the environment and the relations with stakeholders". With regard to the concept of stakeholder and CSR, Freeman (1984) first introduced the stakeholder concept to social responsibilities. It is "any group or individual who can affect or is affected by the achievement of the organization's objectives". Matten et al. (2003) mention that the stakeholder theory is "a necessary process in the operationalisation of corporate social responsibility, as a complimentary rather than conflicting body of literature". Stainer (2006) mentions that companies should focus, at least, on the most important stakeholders, identifying their expectations, while the World Business for Sustainability Development (1998) states that companies should meet the changing expectations of the stakeholders. Maignan and Farrell (2004) also, define the concept of CSR as the satisfaction of the stakeholders' demands. According to Carroll (1979), CSR means that companies respond to economic, legal, ethical and discretional expectations. As it is not feasible for companies to satisfy all stakeholders' expectations, Maignan and Ferrell (2004), Craig (2003) and 
Donaldson and Preston (1995) suggest that companies are responsible only for their corporate stakeholders.

During the last 15 years there is an increased trend of CSR reporting in developed economies (Bebbington et al. 2008). Frederick (1978) and Perrini (2005) show that CSR and CSR/Non Financial Report, have emerged together. Podnar and Jancic (2006) recommend that companies "do not and cannot treat all stakeholders equally or communicate with them with the same intensity". Dimensions of CSR report have been analyzed extensively in different countries such as New Zealand (Hackston and Milne, 1996), Bangladesh (Belal, 2001) Ireland (Douglas et al. 2004), UK (Idowu and Towler, 2004), Australia, Slovenia (Golob and Bartlett, 2007), Switzerland (Birth and Illia, 2008), Egypt (Rizk et al., 2008) and Finland (Tuominen et al., 2008). The majority of the studies take into account different sectors while there are a few studies that apply to specific sectors such as financial institutions (Douglas et al. 2004), media sector (Waller and Lanis, 2009) and forest industry (Tuominen et al., 2008). Idowu and Papasolomou (2007) conclude that there are four reasons for CSR reporting: corporate reputation, stakeholder's pressure, economic performance, genuine concern and broad social/cultural reasons. Mitnick (2000) mentions that companies tend to avoid reporting issues with low performance while they refer to a great extent on topics with high levels of performance. According to Sweeney and Coughlan (2008), the CSR report is only one of the plethora of communication channels that companies use in order to present their practices to stakeholders. Additionally, the non-financial report refers to company's practices in relation to social and environmental concerns increasing their transparency (Ellerup Nielsen and Thomsen, 2007). A notable criticism on the CSR report is that the information provided can be different from the actual corporate actions. The actual CSR performance should not be related to quality and completeness of information on CSR report models (McGuire et al. 1988). The CSR report performance reflects only the degree of transparency to readers while the CSR performance is measured against the actual performance.

The paper concerns both traditional and innovative key elements in CSR communication concentrating on reports and information provided in official corporate sites as they are the major means of reporting in Greece. This study contributes to literature in several ways: classifies, analyzes and interprets the content of CSR information in order to provide readers with what CSR reports and information bodies disclose, introduces innovative dimensions in CSR reporting field, identifies the similarities and differences among the investigated companies in predetermined dimensions and sub-dimensions, concentrates on specific sector and country and promotes the dialogue of CSR report standardization. In this study, the terms of sustainability and social responsibility are used as synonymous (Marrewijk and Were, 2003; Marrewijk, 2003; Dyllick and Hockerts, 2002).

The paper focuses on the companies that operate in telecommunication sector and more specifically to providers of mobile-fixed telephony and internet access services. More specifically, the Greek telecommunication sector has been selected because the CSR penetration in the telecommunication sector seems higher than in the other sectors (Panayiotou et al., 2009) and little attention is paid to it by academic literature (Runhaar and Lafferty, 2009).

The study unfolds as follows: Section 2 presents the literature review of CSR reporting. Section 3 provides information about the telecommunication sector. Section 4 describes the methodology and section 5 provides the analyses of CSR information. In the last part, section 6, the conclusion is presented.

\section{Literature review}

\subsection{Characteristics of CSR reporting}

There are various studies, both by individual authors and by organisations that examine the characteristics of CSR reporting. The CSR Europe (2000) noted that companies adopt different methods to provide their CSR information to their stakeholders. Idowu and Towler (2004) compared the content of CSR report of seventeen UK companies that belong to nine industries. In total, ten report characteristics are indentified in order to record the differences in companies' report practices, namely: stand-alone CSR report, director responsible for CSR, FTSE4Good index, Business in the Community Index, Dow Jones Sustainability Index, ISO 14001 Index, supports named charities, thematic inclusion in CSR report, sets annual targets for CSR and has a Web site for CSR. For the first time innovative dimensions of CSR report are introduced; however, the context of the corporate practices did not elaborate. The KPMG (2005) investigated the top two hundred and fifty companies of the Fortune 500 (G250) and the top one hundred companies in sixteen countries (N100) for Corporate Responsibility (CR) Reporting. The results show that the CR report as a stand-alone report was $70 \%$ of G250 and 50\% of N100. Golob and Bartlett (2007) compared the Australian and Slovenian CSR reporting differences, referring to CSR guidelines and reporting standards such as ISO, Accountability A1000, UN Global Compact and Global Reporting Initiative (GRI). Ellerup Nielsen and Thomsen (2007) based on Fairclough's (1995) model, create an analysis model of CSR report that considers four dimensions, namely: stakeholders (employees, shareholders, customers, suppliers, media and NGO's), context (global/local, CEO/history, market position), perspectives (people, profit and planet) and ambitions (low, 
middle and high). Some of the sub-dimensions, such as CEO, history are not fully elaborated on. Sweeney and Coughlan (2008) examine how stakeholders are considered in the CSR annual report. The content analysis is used for twenty eight companies that belong to different industries and are distinguished by FTSE4Good index. The study indicates that each industry reports its CSR practices considering the stakeholders differently. However, the study investigates only one dimension of reports, the stakeholders. Birth and Illia (2008) mentioned the five most traditionally used communication channels and what each of them contains: internal communication, Web, social report, codes of conduct and stakeholder consultation. Finally, Rizk et al. (2008) identify four disclosure dimensions such as customer, employee, environment and community related to Egyptian corporate entities from different sectors. Sectoral, cultural or national differences within the companies they operate are the major determinants of CSR (Adams et al., 1998; Palazzi and Starcher, 2000; Sachs et al., 2006). However, the majority of the studies focus on a variety of sectors (Sweeney and Coughlan, 2008; Idowu and Towler, 2004; Birth and Illia, 2008; KPMG, 2005; Rizk et al., 2008) and Golob and Bartlett (2007), Rizk et al. (2008) and KPMG (2005) examine characteristics of CSR reports of different countries. All studies neglect important characteristics of CSR reports such as target-setting and performance comparisons which are essential data for a subjective evaluation by stakeholders and a sign of commitment to continuous improvement.

\subsection{Determinants of CSR reporting}

There are numerous factors that can affect the CSR disclosure such as company's size, sector, culture and profitability. The large companies have more shareholders who are probably interested in social issues and social programs (Cowen et al., 1987). Watts and Zimmerman (1978) argue that large companies promote CSR reports mostly in order to avoid the political cost which affects the management wealth. Trotman and Bradley (1981) investigate the characteristics of 207 companies and their social responsibility disclosures. The study shows that the companies which provide social responsibility information are larger in size, have higher systematic or market risk and give stronger emphasis on the long term than companies that do not publish CSR information. Similarly, Patten (1991) investigates 128 companies concluding that size and industry type are significant factors on CSR report. Mathews (1993) supports that cultural and national differences are factors likely to affect CSR reporting. Similarly, Adams et al. (1998) note that the company's size, the industry group and the country where companies operate can affect the CSR disclosure by taking into account one hundred and fifty companies from six different European countries. Cowen et al. (1987) conclude that the company's size and sector correlated with a specific type of social responsibility disclosure while Roberts (1992) support that CSR report is related to the company's size and probably associated with lagged profits. The country where the company operates affected the CSR report and, finally, the factor of industry seems to influence the reports. On the other hand, Davey (1982) and $\mathrm{Ng}$ (1985) note that the company's size and CSR disclosure do not correlate and Balabanis et al. (1998) show that the CSR disclosure does not depend on the industry type. The consumer-oriented industries are more expected to show their companies' practices as this can affect the corporate image and sales (Cowen et al., 1987). There are studies that claim, there is a relationship between profitability and corporate social disclosure (Cowen et al., 1987) while there are others with opposing results (Gray et al., 1995; Ng, 1985). Adams and McNicholas (2007) conclude that the nature of ownership could affect the sustainability reports. Sweeney and Coughlan (2008) look at seven different sectors and find that the CSR report is affected by the sector where the company operates.

\section{Telecommunication sector}

CSR issues are highly relevant to the telecommunication sector in Greece. The telecommunications sector is highly relevant to CSR issues as Most European operators implement CSR practices presenting unique social aspects to other sectors. Finally, little attention is given to the academic literature concerning the telecommunications sector and CSR, (Runhaar and Lafferty, 2009). The telecommunication sector includes companies that provide fixed and mobile telephony services, internet access and other telecommunications services. There are numerous organizations that concentrate on social concerns of telecommunications companies such as European Information Technology Observatory, European Telecommunications Network Operators' Association (ETNO), Global e-Sustainability Initiative, European Union and World Health Organization. At the European level, forty-two full member companies are committed to the ETNO which, among other activities, promote the concept of sustainability in their operations taking into account environmental protection, social progress and economic growth (ETNO). In the case of Greece, mainly four companies seem to take into account CSR. Two companies, Cosmote and OTE, choose to assess their CSR and participate in SRI markets.

In addition, Cosmote, OTE, Vodafone and Wind are the main members of the Hellenic Network for the CSR, whose mission is to promote the concept of CSR in the business community and in the social environment. The only company that is a full member committed to the sustainable actions of ETNO is OTE. All the aforementioned telecommunication companies have a dedicated, independent CSR department which illustrates the high importance 
of CSR in their operations while the majority or all shares belong to individuals. CSR reporting in Greece is voluntary even though in some European countries there is regulatory reporting in the environmental dimension (Douglas et al. 2004). As regards the Greek telecommunication sector, the Hellenic Telecommunications \& Post Commission, the National Regulatory Authority, determines the quality indicators for each type of provider and compels all telecommunication companies to publish them on their official web sites.

\section{Methodology}

\subsection{Content analysis}

The tool of content analysis is widely used in the field of CSR research analyzing non-financial reports (Gray et al., 1995; Hackston and Milne, 1996; Sweeney and Coughlan, 2008; Milne and Adler 1999). It is a process which gathers and codifies both qualitative and quantitative information into pre-defined categories (Guthrie and Abeysekera, 2006). The quantitative approach transforms observations into quantitative statistical data while the qualitative one summarizes and classifies elements or parts of the text material and focuses on intentionality and its implications. Weber (1988) notes that content analysis methodology is meant to codify and compress a text into various categories based on predetermined criteria. Similarly, Krippendorff (1980) considers the content analysis as "a research technique for making replicable and valid inferences from data according to their context" and notes the importance of which content should be analyzed while Powell (1997) defines it as "a systematic analysis of the occurrence of words, phrases, concepts etc. in books, films, and other kinds of materials". Content analysis is a method for the analysis of texts, visual images, illustrations, tables, photographs, cartoons etc (Kondracki et al. 2002). Content analysis is the simplest form for detecting the presence or absence of social responsibility information (Patten and Crampton, 2004). In this study, the qualitative content analysis is defined as subjective interpretation of the CSR information through the systematic classification process of coding and identifying themes (Hsieh and Shannon, 2005). The analysis of different units is used to develop the content analysis process (Gray et al., 1995). Particularly, CSR reports are scrutinized in their entirety for explicit or implicit meaning concerning the concept of CSR. The information is identified, sorted and categorised by the report dimensions according to the unit analysis.

\subsection{Research description}

The lack of studies concerning the investigation of major dimensions in one CSR model triggered the interest of the authors. In addition, this study is restricted to an examination of CSR reports on specific sector and country. The study is based on the preliminary CSR report dimensions and sub dimensions proposed by Sweeney and Coughlan (2008), Idowu and Towler (2004) and Ellerup Nielsen and Thomsen (2007). Sweeney and Coughlan (2008) adopted content analysis in order to ascertain how organizations are taking a focused stakeholder in CSR field by studying seven different sectors. The stakeholders are categorized into two different dimensions, the primary and the secondary. Idowu and Towler (2004) analyzed the content of CSR reports presenting what information is provided to readers. Ellerup Nielsen and Thomsen (2007) followed a semantic topic analysis and an analysis of textual and rhetorical features to show what discourse strategies are adopted by the organizations. A significant methodological limitation of the studies is the lack of specific unit analyses that the identification and description process were based on. However, the suggested models are expanded to include more dimensions and sub dimensions in order to investigate more CSR report characteristics consistent with theories and literature on CSR reports.

According to ICAP $(2007 \mathrm{a}, \mathrm{b})$ reports for fix-mobile telephony and internet access providers, there are 20 companies that operate in the Greek telecommunication sector. The authors analyzed the content of CSR reports and official corporate web sites, as they are the main means in order to communicate with society and it is expected to provide holistic information on the CSR concept. In total, five companies were taken into account for a content analysis, namely: Cosmote, Forthnet, OTE, Vodafone and Wind. The analysis of CSR reports or information bodies are categorized in four main predetermined dimensions and eleven sub-dimensions. The first dimension, type of communication, looks at whether the CSR information is provided through a stand-alone report or company's official web site and whether an English version of CSR information exists. The stand alone report indicates a clear CSR communication policy in order to gain a sense of legitimacy from stakeholders and society. The English version of CSR reports informs stakeholders globally about implemented CSR initiatives as environmental and social initiatives are at the center of global consideration. The Greek telecommunication operators are internationally oriented because either they are subsidiaries of international companies or operate in other countries such as in the Balkan area.

The second dimension concerns whether the context is international and/or nationally oriented, refers to the main stakeholders and provides specific initiatives for each CSR concern. The international oriented context refers to initiatives in countries where they operate. As CSR covers multiple stakeholders, a CSR report should include 
initiatives for the most important stakeholders, such as customers, to the less important ones. The description of specific initiatives gives the opportunity for readers to understand what exactly CSR means for the company and how CSR is developed.

The third dimension takes into account the existence of targets for each of the proposed indicators, the presentation of quantifiable data and the performance comparison with previous time periods. Setting targets is an important innovative component for a CSR report because it is a sign of commitment to continuous improvement. With quantifiable data and the comparability of performance in CSR reports, each reader can easily judge and compare the CSR performance during the years or among operators. The last dimension, distinctions, concerns the publication of the awards, certifications of management systems such as ISO, OHSAS and BS and report guidelines or frameworks. The importance of distinctions is that they reflect the degree of transparency and evidence of accountability in reporting. Finally, unit analysis, in the content analysis methodology, depends on the research questions; thus, for each dimension and sub-dimension, the following units has been used, Table 1 .

\section{Insert Table 1Here}

\section{Analysis}

This part presents what and how the CSR reports or information bodies on web site provide to readers concentrating on the 4 dimensions schemes mentioning the differences in the companies' reporting dimensions and sub dimensions. The order below is alphabetical.

\section{Cosmote}

Cosmote belongs to the group of OTE and it is activated in Greece and in four South East countries increasing the penetration of telecommunication services. The CSR report in 2007 focused mainly on 3 topics: responsible management, environmental and social responsibility. Additionally, there is a short presentation of the major financial indicators of the Cosmote group. Cosmote depicted its CSR model as a circle where the inner circle refers to responsible business operations, the medium one to environmental responsibility and the external one to social responsibility. The company presents the targets for various specific indicators not only for the previous years but also for the following year and it compares the performance among time periods where suitable specific data are available.

Cosmote considers that CSR creates value for the company, thus, integrates CSR in management and operational procedures. According to Awareness \& Social Behaviour Index (ASBI) (2007), the company took the third place among the most responsible companies. Cosmote certificated its management systems by different external bodies such as BS 25999, ISO 9001:2000, ISO 14001:2004 and OHSAS 18001:1999 and the report follows GRI guidelines. As regards employees, Cosmote spent more than 1.756.000 Euros for training purposes and devoted approximately 58.000 man hours increasing both the participants and the seminars that take place every year. Additionally, the health and safety of employees at work are greatly significant in Cosmote which mentions indicators concerning accidents. Cosmote supports a measurement programme of electromagnetic radiation, namely "Pedion 24 " which results are publicized in order to inform all stakeholders. Furthermore, the company takes care of keeping a responsible communication with its customers considering various practices of responsible marketing. A parental control has been developed so that parents can monitor their children's access. As regards the environment dimension, Cosmote concentrates on four issues: management of natural resources, recycling materials, energy and radiation. Cosmote supports social issues on four major topics: children welfare and development, accessibility for people with disabilities, equal access to education and information and disaster relief. At the end of the report, there is a presentation of the CSR Group Cosmote subsidiaries in other companies both in Greece and abroad. The CSR report exists both in Greek and English edition.

\section{Forthnet}

The official corporate web site is the major mean of Forthnet for the publication of its CSR information and more specifically in the section of "Social Contribution". The company contributes to specific groups of people or organizations concentrating on four dimensions: sports, culture, society and education. The CSR policy integrated by the company is probably limited and does not concentrate on multiple stakeholders. However, CSR information is scattered to different parts of the web site such as awards and certifications which are not published in the section of "Social Contribution" but in the "Press Release" and "Research and Development" section, respectively. CSR information is provided both in Greek and English versions. At this point, it is worth noting that Forthnet probably integrates numerous CSR practices but does not publish them in its web site.

\section{OTE}

OTE S.A is the largest telecommunication operator in Greece which belongs to FTSE/Athex-20 in Athens Stock 
Exchange and is traded on New York (NYSE) and London (LSE) Stock Exchanges. The company has adopted the term of Corporate Responsibility (CR) and its reports have published annually since 2005 . At the beginning of the report, information is given regarding the OTE group, the provided services and the countries where its subsidiaries operate. According to the latest available report in 2007, the company revolves around four broad issues: marketplace, employees, environment and society.

As regards the first dimension, OTE S.A introduces new technologies and broadband services. An important topic in this dimension is the company's efforts to decrease the digital gap by integrating activities such as building up the infrastructure in remote areas or areas with low population, customers' education on the benefits of new technologies and equal access for people with special needs. In this dimension, issues regarding customers, procurement procedures, research programmes and regulation issues are included. In the employee dimension, numerous are the practices such as supplementary insurance, financial benefits rewarding the best employee, improvements of conditions on work places and activities in order to secure the health and safety of the employees. The environmental dimension includes the support of NGOs initiatives specialized in the protection of the environment, the recycling of telecommunication components, the protection of natural resources and the promotion of renewable energy sources. The dimension of society embraces practices in order to reinforce corporate volunteering, sponsorships and donations. It is obvious that the report notes specific practices for each stakeholder publishing specific targets and data comparing the performance of indicators. Finally, the reader can be informed for the CSR practices of OTE's subsidiaries such as Cosmote, OTENET, OTEplus, OTEAcademy and Romtelecom. The CR report is designed and conducted in accordance with GRI guidelines and certified as grade "B". OTE is certificated by ELOT EN ISO 9001:2000, ELOT EN ISO 14001:2004, ELOT 1801:2007 and FTSE4Good in order to verify its management systems. OTE corporate responsibility is recognized by consumers as it is included in ASBI (2007) list. Finally, OTE took the 2nd award "CEO \& CSR: Best CSR web site" for CSR topics presented in its official web site in the conference "CEO \& CSR 2008" in Athens. Both Greek and English reports are available by OTE SA.

\section{Vodafone}

The Greek Vodafone is owned at 99.8 percent by Vodafone Group Plc. It provided a stand-alone CR report, for the period of April 2007-March 2008, of eighty seven pages divided into eight sections, namely, management of CR, environment, mobile phones-masts-health-network deployment, access to communications, customers, supply chain, employees and social investment.

The first section of the report mentions that the CR is integrated into the company's vision, values, goals, principles, strategy and governance. It is the only company in the telecommunication sector that has adopted an identification process since 2005 for its stakeholders assessing the business impact on them. The section of suppliers includes a code of ethical purchase and evaluation procedure taking into account major issues such as work hours, child labour and environment. The company provides to suppliers the opportunity to mention any concern regarding the supplying procedure. As far as customers are concerned, Vodafone has integrated practices in order to ensure and increase customers' trust and integrates activities for a safer use of mobile phone from children and adolescents. The company takes into account CSR practice issues that are most important in telecommunication sector such as access to communication and health concerns. Vodafone informs the general public regarding the function of the new technology, mobile telecommunication and supports information programmes in order to measure and check the radio frequency electromagnetic radiation and publishes the results. Concerning the environment, it takes into account practices such as recycling in order to decrease the environmental impact. As regards the digital divide, the company offers products and services to groups of people with special needs. In the social investment section, Vodafone considers children as an important group of the society, thus, supports those adopting multidimensional programmes. Employee surveys are conducted in order to raise concerns on different aspects. The CSR report presents different indicator targets and demonstrates the progress of the major stakeholders. Vodafone certificates its management systems by different standards such as ISO 14001, EMAS, OHSAS 18001, ISO 19001, and BS 7799. Additionally, it is the only report which provides a limited number of negative information i.e. the security interception problems in 2005. Vodafone's CSR report is verified by GRI in order the results to be reported objectively and subjectively and they have published since 2002-2003. Finally, the report is translated into English language.

\section{Wind}

Wind Hellas is a part of the Weather Investments Group which owns the Wind Telecommunicazioni spa that operates in mobile and fixed telephony in Italy. The company publishes CSR information in its official web site in the section of "In Practice Social Responsibility Wind" contrary to Forthnet where CSR information is scattered to 
different sections of its web site. There are three main dimensions Wind focuses on, namely, business, environment and society. Regarding the first dimension, the work place is an important sub-dimension since the company believes that its employees are important determinants for its reputation and success, adopting various practices such as code behaviour and giving priority to their health and safety. Another sub-dimension is the market where a snapshot of information is promulgated for various stakeholders such as customers and suppliers. As regards the environment dimension of CSR, Wind undertakes an electromagnetic radiation measurement in order to design and develop its infrastructure responsibly and to inform its customers on the safe use of mobile telecommunication. Other adopted practices are management of waste components, energy sources and green actions. In the third dimension, Wind directly or indirectly supports different groups of people and organizations while sponsors a number of social activities such as sports, theatre and music. The web site includes information concerning the principle codes, the external certifications such ISO 9001:2000 and ISO 14001:2004, human resources and information to parents regarding mobile telecommunications. Finally, there is a special section which explains to customers how the mobile infrastructure and network work. The CSR information is published in Greek and English editions.

The examined CSR reports are similar with respect to structure, content and analysis. In table 2, there is a presentation of the CSR report characteristics where differences and similarities among them can be observed. In the first dimension, three out of five companies prefer to publish information in a stand-alone annually CSR report, as numerous European telecommunication operators do, while the other two use their web site where the time period they refer to is unclear. In the first case, companies that publish stand-alone reports use their web site as a communication mean simultaneously but the reports are more informative and explanatory than the web sites. Moreover, except for a holistic report on the concept of CSR, companies publish thematic reports or information such as "Mobile Telephony in our Life" (Wind), "Parents Guide to Mobile Telecommunications" (Vodafone), "Parental Control Services" (Cosmote) because it is impossible in a single report to address all diverse concerns of stakeholders., It should be noted at this point that the Greek Vodafone appears to be affected by Vodafone Group Plc as all the reports of the Group have common characteristics. Finally, all companies publish their reports or information in English probably because the foreign stakeholders, mainly the investors, take into account the concept of CSR more seriously intending to maximize the benefits. As regards the second dimension, except for Forthnet, all companies approach the CSR concept as a multiple construct, thus, refer to the major stakeholders confirming the six categories of section 1: suppliers, management of CSR (corporate governance), environment, employees, customers and community, reporting specific practices in order to be more efficient. As in the case of Greek companies, numerous European telecommunication companies follow a multi-stakeholder approach. Concerning the content orientation, Cosmote and OTE have an international and national orientation context because both operate in foreign markets such as Balkan countries.

Two groups of companies are distinguished concerning the dimension of indicators, the first includes Cosmote, OTE S.A and Vodafone which set targets, provide specific data and report performance progress back to readers. The second group includes Forthnet and Wind which prefer not to expose such informative data. Regarding the last dimension, all companies publish their management system certifications and awards and three of them mention which standard report guidelines they adopt as the reporting is considered the most visible issue of CSR practices. Companies choose to mention their distinctions in order to increase the interest of media and make the report more attractive to the readers. It can be inferred that highly recognized telecommunication operators such as Cosmote, OTE SA and Vodafone intend to publish information in their annual reports as much as possible covering all topics that could interest a reader. A similar conclusion might not be reached for Wind and, mainly, Forthnet even if Wind is considered a highly recognized company too. It is probable that the CSR reporting policy is not only affected by the specific company's characteristics but also by the management board or CSR departments and employees which can determine the CSR and CSR reporting policy.

\section{Insert Table 2 Here}

\section{Conclusions}

The global business community has agreed on how a financial report should be structured and what information should be included through international accounting standards. In the case of CSR report, the study supports the conclusion that more dialogue for standardization of CSR reporting should be made as there is no widely accepted reporting standards to regulate it. Undoubtedly, CSR communication and reporting is considered one of the major issues of CSR implementation as through them companies legitimize their initiatives and ensure transparency. In Greece, the CSR communication, especially in the telecommunication sector, still remains in the infancy stage. The telecommunication companies seem to take more into account the economic concerns and the competitive business environment than the CSR standards in order to gain the "social license" to operate. In the literature review, there is 
lack of studies that investigate the CSR reporting in the telecommunication sector in a specific country. The study provides information concerning the "what" and "how" telecommunication operators make CSR reports in Greece. The study examines five companies' socially responsible information that is available through a stand-alone report or is presented via corporate web site. For the companies that are not included in the study, it can be inferred that either they do not adopt CSR practices in their operations or adopt them, but they do not publish them. In total, four dimensions and eleven sub-dimensions of CSR report or information via web sites are investigated in order to provide what and how the CSR information is presented to readers. The main schemes analysed are distinctions, indicators, context and type of communication. It is easy to conclude that CSR information vary from well organized, developed and sophisticated CSR reports to a simple reference of social contribution compatible to the results of Idowu and Towler (2004). It seems that OTE S.A, Cosmote and Vodafone follow similar policies as regards CSR reporting and information, while Wind complies with five out of eleven sub-dimensions. Forthnet does not follow any specific policy. Finally, the study finds that all companies, except from Forthnet, provide detailed CSR information related especially to their market presence and adopt a holistic approach to CSR.

The suggested model is more sophisticated than previous proposed ones because it includes supplementary dimensions and it is adaptable to the Greek telecommunication sector. Not only can it be used in order to reveal what and how a company's information is presented to readers but also it can be used by the top level managers to form an in-depth picture of the reporting strategies that each competitor applies for. Companies reinforce their communication with stakeholders by embodying innovative dimensions in their CSR reports according to well defined models improving strategically their communication policy. Such models could be evidence for a trend concerning convergence or divergence in CSR reporting between Greek and foreign telecommunication providers, even if different socio-cultural, economic structure and legal constraints distinguish each country. A CSR report can provide transparency and evidence of accountability; thus, further studies are needed in order to standardize or regulate the CSR reporting in terms of what should be reported and how that is done. For a study on regulation in Greece see Lazarides (2010). The standardization process should incorporate not only international reporting expectations but also the local ones as different cultural and national differences and sectoral characteristics within companies are unique. Finally, it is very important for companies to investigate which stakeholder's interest is addressed to each of the CSR communication tools in order to adapt their published CSR information.

\section{References}

Adams, C.A. \& McNicholas, P. (2007). Making a difference. Sustainability reporting, accountability and organisational change. Accounting, Auditing \& Accountability Journal, 20 (3), 382-402, doi:10.1108/09513570710748553, http://dx.doi.org/10.1108/09513570710748553

Adams, C.A., Hill, W.Y. \& Roberts, C.B. (1998). Corporate social reporting practices in Western Europe: legitimating corporate behaviour?. British Accounting Review, 30, 1-21, doi:10.1006/bare.1997.0060, http://dx.doi.org/10.1006/bare.1997.0060

Balabanis, G., Philips, H. \& Lyall, J. (1998). Corporate Social Responsibility and economic performance in the top British companies: Are they linked?. European Business Review, 98 (1), 25-44, doi:10.1108/09555349810195529, http://dx.doi.org/10.1108/09555349810195529

Bebbington, J., Larrinaga, C. \& Moneva, J.M. (2008). Corporate social reporting and reputation risk management. Accounting, Auditing \& Accountability Journal, 21, 337-361, doi:10.1108/09513570810863932, http://dx.doi.org/10.1108/09513570810863932

Belal, A.R. (2001). A Study of Corporate Social Disclosures in Bangladesh. Managerial Auditing Journal, 16 (5), 274-289, Doi:10.1108/02686900110392922, http://dx.doi.org/10.1108/02686900110392922

Birth, G. \& Illia, L. (2008). Communicating CSR: practices among Switzerland's top 300 companies. Corporate Communications: An International Journal, 13, 182-196, doi:10.1108/13563280810869604, http://dx.doi.org/10.1108/13563280810869604

Carroll, A.B. (1979). A three-dimensional conceptual model of corporate performance. Academy of Management Review, 4 (4), 497-505, doi: 10.2307/257850, http://dx.doi.org/10.2307/257850

Cosmote, [Online] Available at: http://www.cosmote.gr/content/el/attached_files/Company/KoinonikosApologismos/KoinonikosApologismos2009.p df (December 1, 2010) 
Cowen, S.S., Ferreri, L.B. \& Parker, L.D. (1987). The impact of corporate characteristics on social responsibility disclosure: a typology and frequency-based analysis. Accounting, Organisations and Society, 12, 111-122, doi:10.1016/0361-3682(87)90001-8, http://dx.doi.org/10.1016/0361-3682(87)90001-8

Craig, S.N. (2003). Corporate Social Responsibility: whether or how. California Management Review, 45, 52-76.

CSR Europe. (2000). Communicating Corporate Social Responsibility. CSR Europe Publications, Brussels.

Davey, H.B. (1982). Corporate social responsibility disclosure in New Zealand: an empirical investigation. unpublished working paper, Massey University, Palmerston North.

Donaldson, T. \& Preston, L.E. (1995). The stakeholder theory of the corporation: concepts, evidence, and implications. Acad Manage Rev, 20, 65-91, Doi:10.2307/258887, http://dx.doi.org/10.2307/258887

Douglas, A., Doris, J. \& Johnson, B. (2004). Corporate social reporting in Irish financial institutions. The TQM Magazine, 16 (6,) 387-395, doi:10.1108/09544780410563301, http://dx.doi.org/10.1108/09544780410563301

Dyllick, T. \& Hockerts, K. (2002). Beyond the business case for corporate sustainability. Business Strategy and the Environment, 11, 130-141, doi:10.1002/bse.2, http://dx.doi.org/10.1002/bse.2

Ellerup Nielsen, A. \& Thomsen, C. (2007). Reporting CSR - what and how to say it?. Corporate Communications: An International Journal, $12 \quad$ (1), 25-40, doi:10.1108/13563280710723732, http://dx.doi.org/10.1108/13563280710723732

European Commission. (2001). Green Paper: Promoting a European framework for Corporate Social Responsibility. Brussels.

European Telecommunications Network Operators' Association, [Online] Available at: http://www.eett.gr/opencms/opencms/EETT/Electronic_Communications/Telecoms/QualityIndicators/(December $25,2010)$

Forthnet, [Online] Available at: www.forthnet.gr (December 1, 2010)

Frederick, W.C. (1978). From CSR1 to CSR2: The Maturing of Business-and-Society Thought. Working Paper, $n$. 279, Graduate School of Business, University of Pittsburgh.

Freeman, R.E. (1984). Strategic Management: A Stakeholder Approach, Pitman, Boston, MA.

FTSE4Good. (2010). [Online] Available at: http://www.ftse.com/Indices/FTSE4Good_Index_Series/index.jsp (December 18, 2010)

Global Reporting Initiative (GRI). (2010). [Online] Available at: www.globalreporting.org (December 10, 2010)

Golob, U. \& Bartlett, J.L. (2007). Communicating about corporate social responsibility: A comparative study of CSR reporting in Australia and Slovenia. Public Relations Review, 33, 1-9, doi:10.1016/j.pubrev.2006.11.001, http://dx.doi.org/10.1016/j.pubrev.2006.11.001

Gray, R., Kouhy, R. \& Lavers, S. (1995). Methodological themes: constructing a research database of social and environmental reporting by UK companies. Accounting, Auditing and Accountability Journal, 2, 78-101, doi:10.1108/09513579510086812, http://dx.doi.org/10.1108/09513579510086812

Guthrie, J. \& Abeysekera, I. (2006). Content analysis of social, environmental reporting: what is new?. Journal of Human Resource Costing \& Accounting, 10 (2), 114-126, doi:10.1108/14013380610703120, http://dx.doi.org/10.1108/14013380610703120

Hackston, D. and Milne, M.J. (1996). Some determinants of social and environmental disclosures in New Zealand companies. Accounting, Auditing \& Accountability Journal, 9, 237-256, doi:10.1108/09513579610109987, http://dx.doi.org/10.1108/09513579610109987

Hellenic Network for CSR, [Online] Available at: http://www.csrhellas.org/portal/portal.php?\&lang=(December 7, 2010)

Hellenic Telecommunications \& Post Commission, [Online] Available at: http://www.eett.gr/opencms/opencms/EETT/Electronic_Communications/Telecoms/QualityIndicators/ (December 19, 2010)

Hsieh, H.F. and Shannon, S.E. (2005). Three Approaches to Qualitative Content Analysis. Qualitative Health Research, 15, 1277-1288, doi:10.1177/1049732305276687, http://dx.doi.org/10.1177/1049732305276687

ICAP. (2007a). Fixed and mobile telephony services, Sector study, Athens.

ICAP. (2007b). Internet access services, Sector study, Athens. 
Idowu, S.O. \& Papasolomou, I. (2007). Are the corporate social responsibility matters based on good intentions or false pretences? An empirical study of the motivations behind the issuing of CSR reports by UK companies. Corporate Governance, $\quad 7, \quad 136-147, \quad$ doi:10.1108/14720700710739787, http://dx.doi.org/10.1108/14720700710739787

Idowu, S.O. \& Towler, B.A. (2004). A comparative study of the contents of corporate social responsibility reports of UK companies. Management of Environmental Quality: An International Journal, 15 (4), 420-437, doi:10.1108/14777830410540153, http://dx.doi.org/10.1108/14777830410540153

Kondracki, N.L., Wellman, N.S. \& Amundson, D.R. (2002). Content Analysis: Review of Methods and Their Applications in Nutrition Education. J Nutr Educ Behav, 34, 224-230, doi:10.1016/S1499-4046(06)60097-3, http://dx.doi.org/10.1016/S1499-4046(06)60097-3

KPMG. (2005). KPMG International Survey of Corporate Sustainability Reporting 2005, KPMG, Leeds.

Krippendorff, K. (1980). Content Analysis: An Introduction to its Methodology, Sage, New York, NY.

Lazarides, Th. (2010). Corporate Governance Law Effect in Greece. Journal of Financial Regulation and

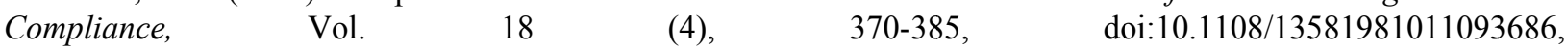
http://dx.doi.org/10.1108/13581981011093686

Maignan, I. \& Farrell, O.C. (2004). Corporate Social Responsibility and Marketing: An Integrative Framework. Journal of the Academy of Marketing Science, 32, 3-19, doi:10.1177/0092070303258971, http://dx.doi.org/10.1177/0092070303258971

Marrewijk, M. van. \& Werre, M. (2003). Multiple levels of corporate sustainability. Journal of Business Ethics, 44 (2/3), 107-19, doi: 10.1023/A:1023383229086, http://dx.doi.org/10.1023/A:1023383229086

Marrewijk, M. van. (2003). Concepts and Definitions of CSR and Corporate Sustainability: Between Agency and Communion. Journal of Business Ethics, 44, 95-105, doi:10.1023/A:1023331212247, http://dx.doi.org/10.1023/A:1023331212247

Mathews, M. (1993). Socially Responsible Accounting. Chapman \& Hall, London.

Matten, D., Crane, A. \& Chapple, W. (2003). Behind the Mask: Revealing the True Face of Corporate Citizenship. Journal of Business Ethics, 45 (1/2), 109-120, doi:10.1023/A:1024128730308, http://dx.doi.org/10.1023/A:1024128730308

McGuire, J.B., Sundgren, A. and Schneeweis, T. (1988). Corporate Social Responsibility and Firm Financial Performance. Academy of Management Journal, 31 (4), 854-872.

Milne, M., \& Adler, R. (1999). Exploring the reliability of social and environmental disclosures content analysis. Accounting, Auditing and Accountability Journal, 12, 237-49, doi:10.1108/09513579910270138, http://dx.doi.org/10.1108/09513579910270138

Mitnick, B. (2000). Commitment, revelation, and the testaments of belief: The metrics of measurement of corporate social performance. Business \& Society, 39 (4), 419-456, doi:10.1177/000765030003900405, http://dx.doi.org/10.1177/000765030003900405

Ng, L.W. (1985). Social responsibility disclosures of selected New Zealand companies for 1981, 1982 and 1983. Occasional paper No. 54, Massey University, Palmerston North.

Palazzi, M. and Starcher, G. (2000). Corporate Social Responsibility and Business Success, The European Baha'i Business Forum, Paris.

Panayiotou, N.A., Aravossis, K.G. \& Moschou, P. (2009). Global Practices of Corporate Social Responsibility. Idowu, S.O. and Leal Filho, W., Springer Berlin Heidelberg.

Patten, D.M. \& Crampton, W. (2004). Legitimacy and the internet: an examination of corporate web page environmental disclosures. Advances in Environmental Accounting and Management, 2, 31-57, doi:10.1016/S1479-3598(03)02002-8, http://dx.doi.org/10.1016/S1479-3598(03)02002-8

Patten, D.M. (1991). Exposure, Legitimacy and Social Disclosure. Journal of Accounting and Public Policy, 10 (4), 297-308, Doi: 10.1016/0278-4254(91)90003-3, http://dx.doi.org/10.1016/0278-4254(91)90003-3

Perrini, F. (2005). Building a European Portrait of Corporate Social Responsibility Reporting. European Management Journal, 23 (6), 611-627, doi:10.1016/j.emj.2005.10.008, http://dx.doi.org/10.1016/j.emj.2005.10.008 
Podnar, K. \& Jancic, Z. (2006). Towards a Categorization of Stakeholder Groups: An Empirical Verification of a Three-Level Model. Journal of Marketing Communications, 12 (4), 297-308, doi:10.1080/13527260600720376, http://dx.doi.org/10.1080/13527260600720376

Powell, R. (1997). Basic Research Methods for Librarians. 3rd ed., Ablex Publishing Corporation, London.

Rizk, R., Dixon, R. \& Wwoodhead, A. (2008). Corporate social and environmental reporting: a survey of disclosure practices in Egypt. Social Responsibility Journal, 4, 306-323, doi:10.1108/17471110810892839, http://dx.doi.org/10.1108/17471110810892839

Roberts, R.W. (1992). Determinants of corporate social responsibility disclosure: an application of stakeholder theory. Accounting, Organisations and Society, 17 (6), 595-612, doi:10.1016/0361-3682(92)90015-K, http://dx.doi.org/10.1016/0361-3682(92)90015-K

Runhaar, H. \& Lafferty, H. (2009). Governing corporate social responsibility: an assessment of the contribution of the UN Global Compact to CSR strategies in the telecommunications industry. Journal of Business Ethics, 84, 479-495, doi:10.1007/s10551-008-9720-5, http://dx.doi.org/10.1007/s10551-008-9720-5

Sachs, S., Maurer, M., Rühli, E. \& Hoffmann, R. (2006). Corporate Social Responsibility for a "stakeholder view", perspective: CSR implementation by a Swiss mobile telecommunication provider. Corporate Governance, 6, 506-15, doi:10.1007/s10551-008-9720-5, http://dx.doi.org/10.1007/s10551-008-9720-5

Stainer, L. (2006). Performance management and corporate social responsibility: the strategic connection. Strat. Change, 15, 253-264, doi:10.1002/jsc.761, http://dx.doi.org/10.1002/jsc.761

Sweeney, L. \& Coughlan, J. (2008). Do different industries report Corporate Social Responsibility differently? An investigation through the lens of stakeholder theory. Journal of Marketing Communications, 14 (2), 113-124, doi:10.1080/13527260701856657, http://dx.doi.org/10.1080/13527260701856657

Trotman, K.T. \& Bradley, G.W. (1981). Associations Between Social Responsibility Disclosure and Characteristics of Companies. Accounting, Organizations and Society, 6, 355-362, doi:10.1016/0361-3682(81)90014-3, http://dx.doi.org/10.1016/0361-3682(81)90014-3

Tuominen, P., Uski, T., Jussila I. \& Kotonen, U. (2008). Organization types and corporate social responsibility reporting in Finnish forest industry. Social Responsibility Journal, 4 (4), 474-490, doi:10.1016/0361-3682(81)90014-3, http://dx.doi.org/10.1016/0361-3682(81)90014-3

Vodafone Group Plc, [Online] Available http://www.vodafone.gr/portal/client/cms/viewCmsPage.action?pageId=1584 (December 1, 2010)

Waller, D.S. \& Lanis, R. (2009). Corporate Social Responsibility Disclosure of Advertising Agencies: An Exploratory Analysis of Six Holding Companies Annual Reports. Journal of Advertising, 38, 109-121.

Watts, R.L. \& Zimmerman, J.L. (1978). Towards a Positive Theory of the Determination of Accounting Standards. The Accounting Review, 53, 112-134.

Weber, R.P. (1988), Basic Content Analysis, Sage University Paper Series on Quantitative Applications in the Social Sciences, Series No. 07-049, Sage, Beverly Hills, CA and London.

Wind, [Online] Available at:

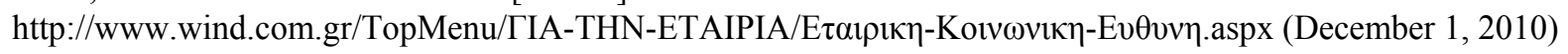

World Business Council for Sustainable Development, (1998), Meeting changing expectations: corporate social responsibility, Stakeholder Dialogue on CSR, Geneva. 
Table 1. Units analysis

\begin{tabular}{|l|l|l|}
\hline Dimension & Sub-dimension & Unit analysis \\
\hline \multirow{3}{*}{$\begin{array}{l}\text { Type of } \\
\text { communication }\end{array}$} & $\begin{array}{l}\text { Stand-alone Report } \\
\text { /Web site }\end{array}$ & Pdf (or word) file / Web site \\
\cline { 2 - 3 } & Greek/English & language \\
\hline \multirow{4}{*}{ Indicators } & International/Local & Context \\
\cline { 2 - 3 } & Stakeholders & Context \\
\cline { 2 - 3 } & Specific Practices & Context \\
\hline \multirow{5}{*}{ Distinctions } & Set targets & Numbers or percentages \\
\cline { 2 - 3 } & Specific data & Numeric Data \\
\cline { 2 - 3 } & $\begin{array}{l}\text { Performance } \\
\text { comparison }\end{array}$ & Numeric Data \\
\hline & $\begin{array}{l}\text { Certifications of } \\
\text { Management systems }\end{array}$ & Keywords or Context \\
\cline { 2 - 3 } & $\begin{array}{l}\text { Report guidelines or } \\
\text { frameworks }\end{array}$ & Keywords or Context \\
\hline
\end{tabular}

Source: www: Authors (2010)

Table 2. Differences in the companies' reporting dimensions and sub-dimensions

\begin{tabular}{|c|c|c|c|c|c|c|}
\hline Dimensions & Sub-dimensions & Cosmote & Forthnet & OTE S.A & Vodafone & Wind \\
\hline \multirow{2}{*}{ 它 } & Stand-alone report & $\checkmark$ & $x$ & $\checkmark$ & $\checkmark$ & $x$ \\
\hline & $\begin{array}{l}\text { Greek/English } \\
\text { version }\end{array}$ & $\checkmark$ & $\checkmark$ & $\checkmark$ & $\checkmark$ & $\checkmark$ \\
\hline \multirow{3}{*}{ 気 } & $\begin{array}{l}\text { International/ Local } \\
\text { orientation }\end{array}$ & $\checkmark$ & $x$ & $\checkmark$ & $x$ & $x$ \\
\hline & Stakeholders & $\checkmark$ & $x$ & $\checkmark$ & $\checkmark$ & $\checkmark$ \\
\hline & Specific Initiatives & $\checkmark$ & $x$ & $\checkmark$ & $\checkmark$ & $\checkmark$ \\
\hline \multirow{3}{*}{ 氖 } & Set targets & $\checkmark$ & $x$ & $\checkmark$ & $\checkmark$ & $x$ \\
\hline & Specific data & $\checkmark$ & $x$ & $\checkmark$ & $\checkmark$ & $x$ \\
\hline & $\begin{array}{l}\text { Performance } \\
\text { comparison }\end{array}$ & $\checkmark$ & $x$ & $\checkmark$ & $\checkmark$ & $x$ \\
\hline \multirow{3}{*}{ 哭 } & Awards & $\checkmark$ & $\checkmark$ & $\checkmark$ & $\checkmark$ & $\checkmark$ \\
\hline & $\begin{array}{l}\text { Certifications of } \\
\text { Management } \\
\text { systems }\end{array}$ & $\checkmark$ & $\checkmark$ & $\checkmark$ & $\checkmark$ & $\checkmark$ \\
\hline & $\begin{array}{l}\text { Report guidelines } \\
\text { or frameworks }\end{array}$ & $\checkmark$ & $x$ & $\checkmark$ & $\checkmark$ & $x$ \\
\hline
\end{tabular}

Source: www: Authors (2010) 